\title{
Gender Disparities in Educational Enrolment and Attainment in Sub-Saharan Africa
}

\author{
Thulani Dube (Senior Lecturer and Chairperson)
}

Department of Development Studies, Lupane State University, P.O Box AC255, Ascot, Bulawayo, Zimbabwe

\author{
Doi:10.5901/jesr.2015.v5n3p279
}

\begin{abstract}
The importance of education in the development of human capital has been broadly acknowledged. It has also been argued that improving access to education is central in the achievement of poverty reduction and other millennium development goals (MDGs) in Africa. Gender inequalities remain manifest in many development sectors in Africa including the educational sector. The main objective of this paper was to examine current gender disparity trends in education in sub-Saharan Africa. The paper reviews literature to investigate the nature of gender gaps in educational enrolment and attainment in sub-Saharan Africa. The main objective is to understand the main factors that contribute to the continued disparities between males and females from primary school level through to university level. The paper finds that there is variety of socio-cultural and economic causes responsible for these disparities. The primary driver of poor educational enrolment and attainment has economic foundations. However, gender disparities are largely explained by cultural beliefs and attitudes.
\end{abstract}

Keywords: Gender, Education, sub-Sahara, Disparities, Enrolment

\section{Introduction}

The importance of education in the development of human capital has been broadly acknowledged (Barro \& Lee, 2013). It has also been argued that improving access to education is central in the achievement of poverty reduction and other millennium development goals (MDGs) in Africa (Lewin, 2009:151). Gender inequalities remain manifest in many development sectors in Africa including in educational enrolment and attainment. This paper examines gender gaps in educational enrolment and attainment in sub-Saharan Africa. While different factors may be at play at different levels of education (i.e. primary, secondary and tertiary education), this paper attempts to give a general encompassing picture. It discusses the main trends and the factors driving the evident gender gaps. While enrolment rates have generally improved across the whole of Africa, '...it remains the case that over 32 million children remain out of school, and only two thirds of children reach the last grade of primary school' (Lewin, 2009:151). The larger percentage of these children are girls. This paper reviews literature to understand the contributory factors to these gender imbalances.

\section{Comparative Global View of Gender Inequality in Education}

It should be noted that the problem of gender inequality in education is mostly acute in Sub-Saharan Africa in the poorest countries. In the Western Europe, North America and the Nordic countries, these gender discrepancies have virtually been eliminated or even reversed. Buchmann et. al. (2008:320) note that while educational inequalities have traditionally been against women, this assessment is no longer true in industrialised countries where '...women have come to far outnumber men among new college graduates'. Buchmann et. al. (2008:325) argue that in the United States, by 2005, women constituted $58 \%$ of recipients of Bachelors' degrees and this trend was expected to continue to widen in favour of women. This paper is therefore largely addressing issues in the Sub Saharan region where women and girls continue to lag behind men and boys in accessing education.

\subsection{Gender disparities in literacy rates in Sub Saharan Africa}

The historical dimension of gender inequalities in Sub Saharan Africa is nowhere more imprinted than in the adult literacy rates of countries in the region. For the nine countries shown in the table below for which data was available on adult literacy rates, it will be noted that eight of them show a glaring disparity between male and female adults in terms of literacy. Most of the countries show a disparity of at least $5 \%$ in favour of males. Countries like Togo have higher disparities of over $15 \%$ in favour of males. Only Botswana appears to have a gender gap favouring females. The reasons 
for this unique trend in Botswana are unclear.

\subsection{Gender Disparities in Illiteracy Rates}

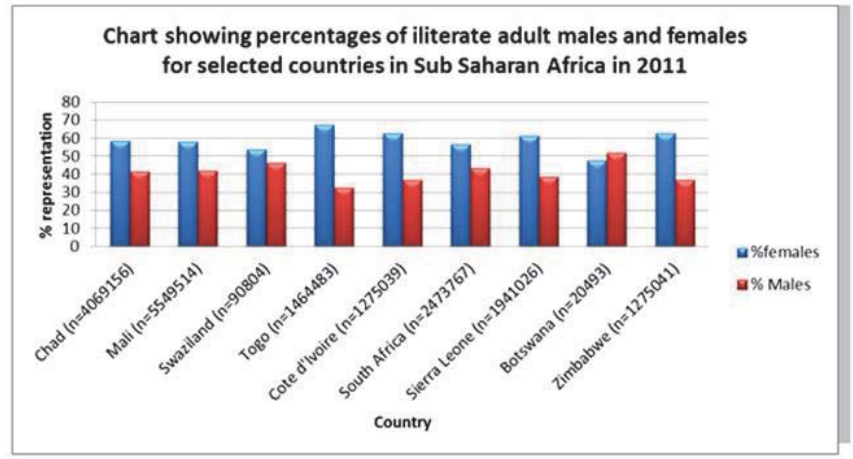

Statistics from UNESCO Institute for Statistics, available from www.stats.uis.unesco.org (Graphs by the author) These statistics are in respect of 2011

\section{Gender Disparities in Primary School Enrolment Rates}

Although disparities between males and females has steadily been closed over the last three decades in sub-Saharan Africa, most countries in the region still exhibit notable gaps in favour of males. This gap is particularly large if we remember that on average, women are $52 \%$ of national populations, although there might be small variations in individual countries. The chart below shows gender gaps in enrolment rates in primary schools in the region. With the exception of Lesotho and Uganda, most countries shown in the chat exhibit disparities in favour of man. Angola has the highest disparity of $23 \%$.

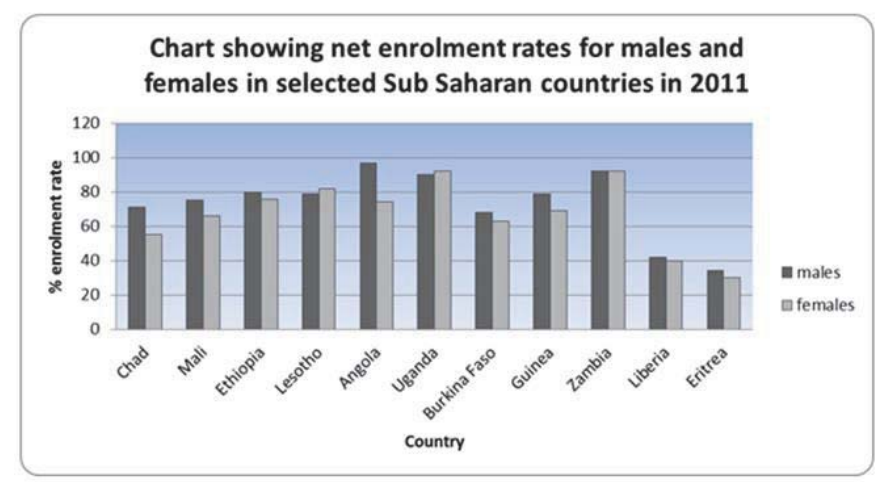

Statistics from UNESCO Institute for Statistics, available from www.stats.uis.unesco.org (Graphs by the author) These statistics are in respect of 2011

\subsection{Disparities in completion rates}

It appears a that combination of economic and social factors play in connivance in preventing girls from gaining access to education at the same rate with boys. Evidence from around the world seems to suggest that poor countries and communities tend to have greater gender disparities in their educational systems while developed countries have virtually overcome the problem. However, gender disparities in the developed world still manifest themselves in the educational 
systems in different ways.

Tansel (2000:467) points out that his research in Turkey points in the direction that income levels affect enrolment and attainment in education. Poverty affects education at two levels - at the level of the household and at the level of the state (Colclough et al , 2000:6). At the level of the household, education is affected by both direct costs and opportunity costs. Direct costs are those expenses incurred in sending the child to school by way of tuition fees, uniforms, bus fare, exercise books and pens, among other things. Opportunity costs constitute the potential income lost because the child is at school. In some developing countries children often have to engage in income generating activities such as selling vegetables in the market. Going to school is often seen as opportunity lost to generate income (Colclough et. al., 2000:17).

Statistics show that school enrolments everywhere in the world are lowest amongst the poorest sections of the community. Colclough et al (2000:6) assert that "Children who do not attend school are overwhelmingly from poor households in poor countries.' However, the view that economic backwardness alone accounts for gender disparities in enrolment and attainment in education must be studied carefully because it does not account for the gender gaps. In the absence of other intervening factors, poverty should affect both boys and girls equally in their enrolment and attainment. We would expect approximately the same number of boys and girls to be at school, although the overall enrolment rate may be low. Likewise, we would also expect their performance to approximately match each other. Poverty alone does not tell us why there is a disparity in numbers according to sex.

In traditional communities, parents tend to invest more favourably in boys with the hope that their investment is not lost because they will benefit from it as social security at old age. This principle has been seen to operate particularly in the selection of children to be sent to school under unfavourable economic conditions. Dorsey (1999:29) shows that when resources are limited and parents have to send children to school, they will opt to send boys at the expense of girls because "... after marriage a daughter's earnings will enrich another man and his family." One way of dealing with the situation by way of policy is to subsidise education heavily in very poor communities. If the element of money and educational expenses is taken out of the equation, this should greatly improve enrolment and attainment for the girl child especially in developing countries. Evidence shows that this policy intervention is effective. In 1980, when Zimbabwe gained its independence from Britain, the new government adopted a policy of education for all by abolishing school fees in primary schools. This resulted in massive improvements in primary school enrolment rates, accompanied by an amelioration of the gender gap at primary school (Dorsey, 1999:35). Swainson (2000:50) points out that the same strategy was effectively applied in Malawi between 1993 and 1995.

In view of the difficulties faced by the girl child, and the small numbers of women making it to the university, the University of Zimbabwe in 1995 introduced an Affirmative Action Policy for girls as an intervention strategy to ease the situation of gender imbalance at the institution. Under this policy female applicants were to be allowed compete for entry into university with two points less than male applicants in every faculty. Although this move reduced the gender gap remarkably, it was met with mixed feelings from various stakeholders.

At the national level, a poor government may fail to provide adequate educational infrastructure in the form of schools. Research has shown that inadequate infrastructure tends to affect the girl child more than the boy child is affected. Evidence shows that the availability of schools at reasonable distances is a major influence on enrolment rates for girls, although this also affects boys to a lesser degree. Commenting on research findings in Guinea and Ethiopia, Colclough et al (2000:21) say that, "Here, as elsewhere, the greater is the distance from home to school, the less likely it is that a child will attend."

Government poverty also often leads to lack of other seemingly unimportant infrastructural provisions that may affect girls' enrolment and attainment at school. A case in point is the issue of separate toilets for girls. Authorities often overlook the special needs of girls as females. Girls often require private facilities to clean themselves. When they have to share toilet facilities with boys, this can become a source of discomfort.

\section{Gender Disparities in Science, Technology and Mathematics Education}

It is broadly accepted that girls and women are underrepresented in Science, Technology and Mathematics education (Miller et. al., 2006). While countries in North America and Western Europe have managed to close the gender based enrolment gaps, this cannot be said about the gender based enrolment and attainment statistics in Science, Technology and Mathematics based studies and career paths. Blickenstaff (2005:369) argues that 'There is no dispute that women are underrepresented in science, technology, engineering and mathematics majors and careers.'

Several explanations have been posited to explain the underrepresentation of girls and women in Science, 
Technology and Mathematics education. These explanations include the following:

a. Biological differences between men and women

b. A difference of gender based attitudes to Science, Technology and Mathematics (STEM)

c. Non-availability of women role models in STEM careers

d. Classroom learning environment

e. The structure of science curricula and the pedagogical approaches taken

f. Childhood socialization and related social pressures

Psychological studies carried out over the years have shown that it is quite likely that men and women have different types of intelligence (Blikenstaff, 2005 \& Hyde, 1996). While these studies found only insignificant differences between men and women in intelligence relating to science in favour of men, it has been suggested that this could be a contributory factor in girls having a limited interest in STEM related subjects and careers. In a related but different study by Miller et. al. (2006) in the United States, it was noted that that girls were generally interested in languages and fine arts while boys were interested more in physical sciences as their favourite subjects. Another factor commonly held responsible for fewer girls and women in science is the view that there are few women role models in STEM related careers. This leads girls to think that such careers are not suitable for them. This problem is further aggravated by the fact that the structure of curricula also reinforces this view where pictorial and textual representations of environments in STEM have traditionally depicted men as the active gender and women as onlookers. Finally, as discussed earlier on, traditional expectations are that a good woman should be feminine and available for her family and home. STEM related jobs have traditionally been considered as a male domain. The husband is seen as the source a woman's needs. Women are thus not challenged to grapple with the challenging matters of life because it is the duty of the husband to deal with them Dorsey (1999:30).

It has also been argued that some male teachers believe that girls cannot perform as well as boys do. A 1994 UNICEF research showed that the attitude of teachers and head-teachers point to the fact that a large number of them did not believe that they discriminate against girls. However, $25 \%$ are reported to have felt that girls are generally poor achievers, and not likely to equal, let alone outperform boys. (Cited in Dorsey, 1999:32). This has fundamental implications on the teachers' treatment and encouragement of the different sexes at school.

Results from single sex schools seem to point to the view that where girls are not measured against boys, they have the capacity to perform outstandingly. One way of overcoming the inferior performance of girls would, thus, be to encourage the development of single sex schools. This would be beneficial to both boys and girls as evidence has shown that results improve also in the boys' schools. However, this has the unfortunate outcome of over-emphasising the difference between boys and girls. Children who attend single sex schools often have a difficult time adjusting to a new environment of mixed sex.

Another culturally entrenched trend that is reported all over the world is the reluctance of both sexes to take certain subjects because they are considered to be suitable only for the "other" sex. Powney (1996:xii) reports that in the UK "gender differences persist at all levels of education with females reluctant to participate in computer studies and males in modern languages."

Another factor that contributes to the disadvantages that girls face in the provision and attainment of education is pregnancy. Thousands of girls dropout of school each year in the third world because of pregnancies. The situation is less apparent in many of the first world where abortion is legal and abortion facilities are readily available. There are no statistics available about the number of girls who dropout of school because of pregnancy. However, Dorsey (1999:32) points out that teenage pregnancies at school are thought to be high in Sub-Saharan Africa. She mentions the case of Zimbabwe. She notes that a large number of these pregnancies are actually caused by male teachers.

\section{Conclusion}

In conclusion, it is noted that educational enrolment and attainment in sub-Saharan Africa remains skewed in favour of boys and against girls. This is particularly so especially amongst the poorest countries and those that have recently suffered conflict such as the Democratic Republic of Congo and Angola. Lack of statistics prevents the creation of a holistic picture about the phenomenon. The enrolment gap begins from primary school level as shown by statistics in this chapter. As educational levels progress, girls face more disadvantages which filter them out of the educational system at a faster rate than boys. Attention is required to address these issues from a policy perspective in individual countries. Further disparities in the education system are seen in the types of subjects that girls and women, boys and man take in the education system with males preferring physical sciences while girls are inclined to arts and social sciences. While 
household level and state level poverty notably affects enrolment rates in general, it is observed that the gender gap in enrolment is essentially a function of socio-cultural effects deriving from attitudes and beliefs about boys and girls.

\section{References}

Azikiwe, U. (1992), Women, Education and Empowerment, Nsukka: Falladu Publishing Company

Ballara, M., (1991), Women and Literacy, London, Zed Books Ltd.

Barro R.J. \& Lee, J.W. (2013) A new data set of educational attainment in the world, 1950-2010, Journal of Development Economics, Vol. 104, pp. 184-198

Bellamy, L.A. and Guppy, N. (1991), Opportunities and Obstacles for Women in Canadian Higher Education, in Gaskell, J., and McLaren A.T., (1991), Women and Education, Alberta, Detselig Enterprises Ltd.

Blickenstaff, J.C. (2005) Women and Science Careers: leaky pipeline or gender filter, Gender and Education, Vol. 17 (4), pp. 369-386

Buchmann, C. \& DiPrete, T.A. and McDaniel, A., (2008) Gender Inequalities in Education, The Annual Review of Sociology, Vol. 34, pp. 319-337

Colclough, C., et al,(2000), Gender Inequalities in Primary Schooling: The Roles of Poverty and Adverse cultural practice, International Journal of Educational Practice, 5(27), pp5-27

Dervarics, C., (2004), Tiny Successes in Bid to close Male-Female Gap in Schooling Worldwide, Population Reference Bureau, [Online] Available: www.popline.org/node/234982 (24 May 2014)

Dorsey, B.J., (1999), Gender Inequalities in Education in the Southern Africa Region: An analysis of Intervention Strategies, Harare, UNESCO Publications

Diven, P., (1998), Women and Non-Formal Education in West Africa: Policy and practice, in Bloch, M., et al (eds.), (1998), Women and Education in Sub-Saharan Africa: Power, Opportunities and Constraints, London, Lynne Rienner Publishers

Hill, M.A., et al, (1993), Women's Education in Developing Countries: An Overview, Baltimore, John Hopkins University Press

Kutnick, P., (2000), Girls, Boys and School Achievement: Critical Comments on who achieves in Schools and under what economic and social conditions achievement takes place - A Caribbean perspective, International Journal of Educational Development, 20(1), pp65-84

Lewin, K.M. (2009) Access to Education in Sub-Saharan Africa: patterns, problems and possibilities, Comparative Education, Vol. 45 (2), pp. 151-174

Miller, H.M., Blessing, J.S. \& Schwartz, S. (2006) Gender Differences in High School Students' Views about Science, International Journal of Science Education, Vol. 28(4), pp. 363-381

Mumba, T., (1995), "Affirmative Action Overdue in Zimbabwe" [Online] Available: http://www.hartford-hwp.com/archives/37/014.html (2 June 2014)

Powney, J., (1996), Gender and Attainment: A Review, Edinburgh, Scottish Council for Research in Education.

Schultz, T.P., (1993), "Returns to Women's Education", in Hill, M.A, et al, (1993), Women's Education in Developing Countries: An Overview, Baltimore, John Hopkins University Press

Swainson, N., (2000), "Knowledge and Power: policies in Education in Malawi, Tanzania and Zimbabwe", International Journal of Educational Development, 20(1), pp49-64

Tansel, A., (2000), "Determinants of School Attainment of Boys and Girls in Turkey: Individual, Household and Community Factors", Economics of Education Review, 21(1), pp445-470

Yu, W., (1995), Women's Education in China, Beijing, Higher Education Press 
